\title{
Bhabha's Notion of Unhomeliness in J. M. Coetzee's Foe: A Postcolonial Reading
}

\author{
Alireza Farahbakhsh \\ $\mathrm{Ph}$. D. in English Literature, University of Guilan, Iran \\ farahbakhsh2000@yahoo.com \\ Rezvaneh Ranjbar \\ M. A. in English Literature, University of Guilan, Iran \\ rezvaneh_ranjbar@yahoo.com
}

\begin{abstract}
The present article aims to offer a postcolonial reading of Coetzee's 1986 novel, Foe based on Bhabha's theories. This article presents two central questions: is it possible to find the traces of Bhabha's concept of unhomeliness in Foe and what does unhomeliness tell us about the characters' cultural identity in Foe. To answer the questions, the researchers do a careful observation of Foe considering Bhabha's notion of unhomeliness. In other words, the manifestation of the concept is explored in Foe through tracing it in the imaginations, actions, behaviors and interactions of the major characters (Susan, Cruso and Friday). The present article reveals that Susan, Friday and Cruso feel unhomely even in their own homeland, a fact which itself adds to their confusion. To put it in another way, Susan, Friday and Cruso move between the two cultures and identities and through the act of imagination they create a new space which does not belong to either one of the two worlds. Also, the article shows that Susan's ambivalent relationship with Friday makes possible the critique of colonial discourses.
\end{abstract}

Keywords: Postcolonial Reading, Coetzee, Bhabha, Identity and Unhomeliness

\section{INTRODUCTION}

One of the most important scopes of English literature is postcolonial literature, "those literatures written in English in formerly colonized societies." ${ }^{[1]}$ As a result, a great number of theoretical concepts have been emerged in this field. Needless to say, aspects of these positions have been developed by a number of different critics, but as Young has stated, "it would be true to say that Said, Bhabha and Spivak constitute the Holy Trinity of colonial discourse analysis, and have to be acknowledged as central to the field." ${ }^{, 2]}$

Bhabha (1949- ), an influential thinker of the 21st century, has coined a conceptual vocabulary for the reading of postcolonial texts. He was born into a small Parsi community from Mumbai, India. He received his B. A. from Bombay University and his M. A. and D. Phil. in English Literature from Christ Church, Oxford University. He was presented the Padma Bhushan award by the Government of India in 2012. In addition to the bulk of articles he has presented, his notable works include Nation and Narration (1990), The Location of Culture (1994), Cosmopolitanisms in Public Culture (2000) and Edward Said: Continuing the Conversation (2005). His prominent theories are expounded in his book, The Location of Culture (1994). In the words of McLeod, Bhabha's "work is very difficult to understand at a first reading because of his compact and complex written style."[3] Bhabha's perspectives on colonialism seek a more intricate perceiving of the present moment. In fact, Bhabha's works "are always written in an ambiguous way, open to different interpretations." $[4]$

Marxism and psychoanalysis have helped Bhabha shape his theory on culture. It is worth noting that the works of Sigmund Freud, the poststructuralists Jacques Lacan and Jacques Derrida and Frantz Fanon's Black Skin, White Masks have had the greatest influences on Bhabha's way of thinking. Chew and Richards have stated that among different postcolonial thinkers, it can be said that "the most Fanonian is Homi K. Bhabha." ${ }^{,[5]}$ Needless to say, Edward Said's Orientalism has made grounds for Bhabha and can be considered as his immediate inspiration. However, According to MooreGilbert, Bhabha mostly emphasizes "the mutualities and negotiations across the colonial divide." [6] 
Bhabha chiefly looks at the interactions between the colonizer and the colonized psychoanalytically and from a different angle; in other words, Bhabha's theory merely shifts our focus. Unlike Said' focus on the colonizer and Fanon's focus on the colonized, Bhabha takes a new perspective and shifts the emphasis toward both the colonizer and the colonized simultaneously.

In The Location of Culture (1994), a collection of his most important essays, Bhabha has coined several concepts about culture that try to undermine the binary oppositions and dividing the world into self and other. The concepts which he constructs, including hybridity, mimicry, ambivalence, liminality, the unhomely, the uncanny and the subaltern have had a great impact on postcolonial discourse. Here, he argues for a theoretical position which escapes the binary oppositions of center and margin, civilized and savage.

As already mentioned, the present article aims to trace and apply Bhabha's notion of unhomeliness to Coetzee's Foe. Accordingly, a few points about Coetzee are presented.

The white South African John Maxwell Coetzee was born in Cape Town on 9 February 1940 to Afrikaner parents. His father was a lawyer and his mother was a schoolteacher. An interesting point about Coetzee's identity is that although he speaks English at home, he was accustomed to speaking Afrikaans with his relatives. He received his B. A. from the University of Cape Town and his $\mathrm{Ph}$. D from the University of Texas. ${ }^{[7]} \mathrm{He}$ has won many literary awards. He was the first novelist to win the Booker Prize twice (first in 1983 for Life and Times of Michael K, and then in 1999 for Disgrace). He has also been awarded the Jerusalem Prize in 1987 for Foe and the Nobel Prize for Literature in 2003.

Aside from his academic works, critical essays and translations from Dutch and Afrikaans, he has produced several notable novels which in the words of Bonnici chiefly "deal with a critique of colonialism, its effects and the historical and ethical restraints on white writers." ${ }^{\text {[8] }}$ His most significant novels include Dusklands (1974), In the Heart of the Country (1977), Waiting for the Barbarians (1980), Life and Times of Michael K (1983), Foe (1986), Age of Iron (1990), The Master of Petersburg (1994), Disgrace (1999), Elizabeth Costello (2003), Slow Man (2005), Diary of a Bad Year (2007) and The Childhood of Jesus (2013). Attwell refers to Coetzee as "a regional writer within South Africa." ${ }^{,[9]}$ Considering Coetzee's oeuvre, it can be seen that many of his novels, including Duskland, In the Heart of the Country, Life \& Times of Michael K, Age of Iron and Disgrace occur in the South African regions, most notably Cape Town. However, some of his novels do not fall into the category of regional writings. For instance, as Easton put it, Waiting for the Barbarians is an invented, non-specific landscape; Foe's location moves from an unnamed island to Bristol and London and other bits of England in between; and The Master of Petersburg travels back in time to Dostoevsky's nineteenth-century Russia. ${ }^{[10]}$ Also, Easton goes on saying that "Through parody and irony, plays on genre and geography, and elaborate intertextuality, Coetzee's novels perform cultural leaps." $" 10]$

Bhabha's notions of hybridity, the unhomely and ambivalence are the main arguments of the present article. The purpose of the article is to demonstrate how Bhabha's interpretation and perception of unhomeliness finds its way into or to put it in another way can be applied in Coetzee's postcolonial novel, Foe. Concentrating on Coetzee's Foe, the study also seeks to show how the issue of identity is explored through Bhabha's notion of unhomeliness. The researchers try to find the manifestation of unhomeliness in Foe through exploring it in the imaginations, actions, behaviors and interactions of the major characters. First, a brief digest of Bhabha's concepts of hybridity, unhomeliness and the related terms and also a brief synopsis of Foe highlighting significant details are presented. Then, through a careful consideration of characters' imaginations, memories and dreams, the manifestation of unhomeliness is discussed in Susan, Friday and Cruso's cultural identity respectively, and finally Susan's relationship with Friday and her authority is challenged and explored in terms of two main concepts, namely, ambivalence and stereotype.

\section{DISCUSSION}

Chinua Achebe has written that under colonization "we lived at the crossroads of cultures. We still do today." ${ }^{[11]}$ Undoubtedly, it is evident that this crossroad for Bhabha is hybridity. In Habib's words, "Hybridity expresses a state of 'in betweenness,' as in a person who stands between two cultures." [12] Bhabha refuses the traditional notion of binary oppositions and rejects Manichean concept that was developed by former postcolonial thinkers such as Fanon and Said. In The Location of Culture, 
Bhabha defines hybridity as what is "new, neither the one nor the other." ${ }^{[13]}$ Central to Bhabha's notion of hybridity is the concept of unhomeliness. As Tyson says, "to be unhomed is to feel not at home even in your own home because you are not at home in yourself: your cultural identity crisis has made you a psychological refugee." ${ }^{[14]}$ As a consequence, unhomeliness makes psychological refugees mix their two cultures. For Bhabha, cultures are hybrid that come after the hybridization. As a consequence, it can be noticed that none of the cultures is pure and genuine. As Huddart has stated, Bhabha "directs our attention to what happens on the borderlines of cultures, to see what happens inbetween cultures." ${ }^{,[5]}$ Bhabha uses the concept of uncanny which is taken from Kristeva. Kristeva extends Freud's sense of a foreignness or the uncanny and believes that we are even foreign to us. There is a sense of foreignness within the self and therefore dividing things into self and other is not plausible. According to Tibile, "Once the binaries are destabilized, Bhabha argues that cultures can be understood to interact, transgress, and transform each other in a much more complex manner than the traditional binary oppositions can allow."[16]

According to Bhabha, "The objective of 'colonial discourse' is to construe the colonized as a population of degenerate types on the basis of racial origin, in order to justify conquest." ${ }^{\text {"13] }}$ Bhabha takes a different perspective and in the words of McLeod, argues that "this important aim is never fully met. This is because the 'discourse of colonialism' does not function according to plan because it is always pulling in two contrary directions at once." ${ }^{[3]}$ McLeod adds that having been considered as the other in the view of the colonizer, the colonized is put outside the western culture. On the contrary, the colonizer is trying to domesticate the colonized and bringing them inside the culture of the colonizer via creating stereotypes; Bhabha believes the two contrary positions (being inside and outside the colonizer culture) lead to the ambivalence and they are always moving in these two directions. ${ }^{[3]}$ Also, Bhabah states that "the colonial presence is always ambivalent, split between its appearance as original and authoritative and its articulation as repetition and difference." ${ }^{,[13]}$ Thus, he strongly believes that this ambivalence leads to the failure of colonial discourse which is itself a place for resisting the colonial domination. In the words of Kraidy, for Bhabha, the concepts of hybridity, unhomeliness, ambivalence and mimicry can be regarded as "the resilience of the subaltern." ${ }^{[17]}$ In Bhabha's viewpoint, the identity and culture of the colonizer is in relation to the culture of the colonized. And it can be noticed that this dependency upon the colonized renders the culture of the colonizer to a state of ambivalence and anxiety rather than authority and power. Before tracing these concepts in Foe, a summary of the novel is presented.

Foe is a rewriting of Daniel Defoe's Robinson Crusoe, with the character Susan Barton representing a female focus seldom observed in such stories. Susan is on a quest to find her kidnapped daughter who has been conveyed to the New World. Her search being unsuccessful, she embarks for Lisbon. Sailing back across the Atlantic, a mutiny on the ship on which Susan is travelling leads to Susan being put aboard a small boat. After being stranded for a short time at sea, she washes ashore on a deserted island inhabited by Cruso and his mute servant Friday who were shipwrecked and came to the island accidently. After a year, a passive ship eventually arrives and rescues them, but Cruso, who has a fever, does not survive and dies en route to England. In England with Friday and in the letters, Susan beseeches Mr. Foe to write and publish her island story. Mr. Foe stresses that Susan's account of her life as a castaway on Cruso's island is not entertaining enough to make a good book. Susan refuses to change the substance of her story, insisting that the story she wants to tell concern her time on the island and nothing more.

Then, Susan and Friday travel to Bristol, where she intends to find a ship that will take Friday back to Africa, but she finds that she cannot trust the captains running the ships. The two make their own way towards Mr. Foe's house which Foe has abandoned because of his own financial problems. Her letters to Foe indicate a troubled doubt as to how much any one is in command of his or her own story. Foe proposes that Susan should attempt to teach Friday to write and she agrees though unwillingly. In the last part, a narrative voice other than Barton appears. In two versions, it depicts the characters in Mr. Foe's house, only Friday is still alive mimicking the sound of island.

As Bhabha mentioned, one aspect of hybridity is unhomeliness. To put it another way, Bhabha refers to a hybrid identity as an unhomely identity (feeling of being caught between two cultures). Needless to say, unhomeliness is not a physical state here. According to Tyson, "Unhomeliness is an emotional state: unhomed people don't feel at home even in their own homes because they don't feel at home in 
any culture and, therefore, don't feel at home in themselves." ${ }^{,[18]}$ The hypothesis, here, is that a feeling of unhomeliness is found in Foe in the case of Susan, Friday and, to a lesser extent, Cruso.

From the very first pages of Foe, it is apparent that Susan moves between two geographical places, the native land (England) and a foreign land (Cruso's island). Foe begins with the description of the moments of Susan's wandering on Cruso's island. Marooned on a deserted island, Susan wants to escape and return to England. In her view, the person who is "accustomed to the fullness of human speech," cannot "be content with caws -and chirps and screeches, and the barking of seals, and the moan of the wind." ${ }^{,[19]}$ She cannot adapt herself to life on the island because she finds island life so unbearable. She spends a little over a year with Cruso and silent Friday on the island. On the island she lives in a hut: "In the hut there was nothing but the bed ... . and in a corner a pile of cured apeskins, that made the hut smell like a tanner's storehouse." ${ }^{[19]}$ But Susan, refusing to use those apeskins, gradually becomes accustomed to island life to the extent that she misses it after leaving the island: "even today when I smell new leather I grow drowsy." ${ }^{[19]}$ She also asserts that "I am becoming an island-dweller. I am forgetting what it is to live on the mainland." ${ }^{[19]}$ It can be said that Susan attempts to view herself as an island-dweller by imitating the island culture while at the same time keeping in touch with her English background. Borbor Comments on the notion of place in Foe by saying that "She [Susan] has become a settler on the island, and thus, her sense of place and her presentation of the island would be different from those of travellers and explorers embarking on an alien land." ${ }^{[20]}$ It can be viewed that Susan is living in in-between space which has played a great role in shaping her state of mind, carrying the meaning of culture. As Krishna asserts, for Bhabha hybridity "is a third space that is neither one nor the other because the translation or encounter between different cultural forms occur in a context where both these spaces are already preoccupied." ${ }^{\text {21] }}$ Bhabha believes that this space signifies a resistance to binaries and unitary identities and cultures. While Susan is on board the ship that rescued them, she describes her feelings as follows: "In England we will have a roof over our heads that no wind can tear off. But did it not seem to you that the moon of our island was larger than the moon of England, as you remember it, and the stars more numerous?" ${ }^{\text {[19] }}$ Later in the second part of Foe, Susan's mixed feeling becomes more obvious when he arrives in England. A good illustration of such feeling is depicted in the scene in which she speaks about her yearning to be on the island:

When I was on the island I longed only to be elsewhere, or, in the word I then used, to be saved. But now a longing stirs in me I never thought I would feel. I close my eyes and my soul takes leave of me, flying over the houses and streets, the woods and pastures, back to our old home, Cruso's and mine. You will not understand this longing, after all I have said of the tedium of our life there. Perhaps I should have written more about the pleasure I took in walking barefoot in the cool sand of the compound. ${ }^{[19]}$

It seems that Susan has internalized the cultural values of the island life. The foregoing statements imply that Susan's imaginations and dreams of Cruso's island (flying over the houses, back to Cruso's hut and walking barefoot) arouse a sense of anxiety and no belonging to her homeland (England) even though she has been settled in England. As a result, Susan ends up being confused: "a being without substance" ${ }^{[19]}$ and getting stuck in between the two worlds (England and Cruso's island). In J.M. Coetzee in Context and Theory, Susan's experience is related to Kristeva's concept of abjection as follows:

In her essay on abjection, Kristeva claims that the abject is also a 'deject' - 'he separates, places, situates himself, he strays' (Kristeva 1982: 8). . . Coetzee gives us an acute sense of Barton's unbelonging, her eternal homelessness, her obsessive desire to be elsewhere. She is a 'deject', she strays. The novelist translates the transcendental homelessness of the modern subject, a subject cast away, into Barton's paradoxical desire for a home and the knowledge of its eternal impossibility. ${ }^{[22]}$

In Bhabha's words, however, "to be unhomed is not to be homeless, nor can the 'unhomely' be easily accommodated in that familiar division of social life into private and public spheres." ${ }^{,[13]}$ It can be said that Bhabha sees unhomeliness as the point from where one might go beyond the binary opposition of homeness and homelessness. It can be observed that Susan, here, gets stuck in between homeness and homelessness. She regards her life as one moving on the threshold of being and non-being. Here, unhomeliness does not signify homelessness but rather an uncanny feeling vacillating between self and other. Another thing to be considered is that as we proceed through the novel, it seems that the 
barriers between the two cultures become less. According to Susan, "the life we lead grows less and less distinct from the life we led on Cruso's island. Sometimes I wake up not knowing where I am." [19] Susan tries to forget that she is on the mainland. She remembers Cruso and his servant Friday, and her good and bad times living with them.

The crisis of cultural identity might be seen in the depiction of Friday through his interactions with other characters. Even though Friday is silent, his identity crisis can be realized. From the beginning, it can be seen that Friday as a subaltern turns toward the colonizer, here Cruso and Susan (after Cruso's death): "Friday has lived with me for many years. He has known no other master. He follows me in all things." "[19] Just like Susan, Friday is also living in in-between space: having an ambivalent personality makes him to live in-between cultures. Friday's cultural identity crisis comes up to him when leaving the island. Friday, seeing that the rescue ship comes ashore, suddenly goes into the hut, takes his spears and then goes into hiding to evade accompanying Susan and the ship crew. As Susan notes,

Whenever I spoke to him I was sure to smile and touch his arm, treating him as we treat a frightened horse. For I saw that the ship and the sailors must be awakening the darkest of memories in him of the time when he was torn from his homeland and transported into captivity in the New World. ${ }^{[19]}$

This scene reveals that perhaps not only does Friday remember his time in Africa, but he also remembers the events leading him to serve as a slave. Moreover, his sense of unhomeliness is intensified when arriving in England. While walking through the streets, he falls into "confusion and distress." ${ }^{\text {[19] }}$ As a consequence, he rarely leaves the house, "being too fearful" [19] His sense of unhomeliness becomes further evident as he dances in Foe's robes and wigs, whirling around. It can be easily understood that he romanticizes his homeland and even Cruso's island: "it was to remove himself, or his spirit, from Newington and England." ${ }^{, 19]}$ This scene can be a good example of the unhomely moments Friday experiences. In his book about the Creole identities of postcolonial literatures, Bongie contends that Friday exists in a trance, "trance being the interval between selfidentity and self-difference," finding himself at a distance from the home. ${ }^{[23]}$ It seems that he neither lives in the present nor in the past. Clinging to his life on the island or to his past life in Africa and going along with Susan in England, Friday feels trapped between the two cultures and identities. In other words, he feels unhomely; he does not know to which culture he belongs. Neither one is his home.

As Werbner asserts, "In the colonial encounter, then, it is not just the colonized who are subject to western ways; the colonizers too are transformed." ${ }^{[24]}$ Coetzee's Cruso feels no need for tools; he makes no table or chair, no lamp or candle and no boat. On the island, Susan attempts to gain information from Cruso, but her efforts are in vain. Cruso has no desire to be saved and just spends time making stone walls, laying the groundwork for a terraced farm though he has no seeds to plant. In Marais's words, "the island becomes an 'autonomous place." ${ }^{, 25]}$ Spending some years on a deserted island with a Negro slave, Cruso adapts himself to the new ways of life to the extent that he does not intend to develop or even change his lifestyle. Cruso, to quote Maher, "is no creator, nor has salvaged civilizations." ${ }^{\text {[26] }}$ Cruso, in Susan's view, "though an Englishman was as strange to me as a Laplander." ${ }^{,[19]}$ In fact, Cruso has internalized the cultural values of the island life. This may be best evidenced when Cruso is on the ship. When Cruso understands he is en route to England, "he came to himself and fought so hard to be free that it took strong men to master him and convey him below."[19] Feeling homesick, Cruso passes away on the ship: "But now he was dying of woe, the extremest woe. With every passing day he was conveyed farther from the kingdom he pined for, to which he would never find his way again. He was a prisoner, and I, despite myself, his gaoler." ${ }^{,[19]}$ Cruso's minds might be preoccupied with the memories of the past, with the memories of the island. It might be inferred that it is not clear whether the place they have come to is his home or his prison. It is supposed to be his home, but simultaneously it is like a prison for him. Similarly, Arkinstall states that Coetzee's Cruso prefers death to continuing imprisonment, for him the prison is not on the island, but off it. ${ }^{[27]}$

Unlike Said, Fanon and JanMohamed who principally define colonial relations in terms of Manicheanism, in McEwan's words, Bhabha "emphasizes its [colonial discourse] ambivalence heterogeneity, rather than its fixed homogeneity." "28] According to Britton, for Bhabha, unhomeliness 
is "a state in which the boundaries normally separating private and public are erased." ${ }^{[29]}$ The unhomely has more to do with the uncanny (the confusion between self and other). It is worth saying that for Bhabha the unhomely, often used synonymously with the uncanny, signifies the notion of ambivalence. When Susan washes ashore on the island, she relates her story, her quest for her missing daughter and the mutiny to Cruso, but Cruso asked nothing about her life and instead behaves as if "nodding to himself as though a voice spoke privately inside him that he was listening to." ${ }^{[19]}$ This voice can be taken as the voice of the other existing inside Cruso. According to Macaskill and Colleran, Cruso is considered "sometimes as an almost-absent presence, sometimes as an almostpresent absence." ${ }^{\text {[30] }}$ It can be said that there seems to be a feeling of the uncanny that exists within Cruso since it confuses borders between the self and the other or the presence and the absence in him. It would be simplistic to think that Cruso always represent the self or the colonizer. In the scene where Cruso is on the verge of death, he thinks he is in a prison. He is considered to be the colonized rather than the colonizer.

The relationship between Susan and Friday can be realized as an example for the relationship between the colonizer and the colonized/subaltern. It can be noted that Lacan' concept of 'the mirror stage' is a principal concept to Bhabha's notion of colonial discourse's ambivalence and also the crisis of identity. The question here is to what extent Bhabha's perception of this concept can be applied in Susan and Friday relationships. The mirror stage explains the function of stereotyping productions in colonial discourse. As McRobbie states, for Bhabha "The stereotype produces on the part of the coloniser both power and pleasure and also anxiety and defensiveness." ${ }^{\text {[31] }}$ Similarly, Huddart contends that for Bhabha there is "always both an aggressive expression of domination over the other and evidence of narcissistic anxiety about the self." ${ }^{[15]}$ In Susan-Friday relations, there is an inconsistency between what they say and what they actually do. Susan challenges her authority, repeatedly asserts that Friday is not her slave and is a free man: "Friday was not my slave but Cruso's, and is a free man now. He cannot even be said to be a servant, so idle is his life." ${ }^{[19]}$ However, she forcefully boasts of her civilization, claiming her supremacy over Friday: "If Friday is not mine to set free, whose is he? No man can be the slave of a dead hand." ${ }^{[19]}$ In developing this argument, there is a scene in which Susan, while searching through Foe's belongings, comes across some recorders and takes the smallest one and gives it to Friday. Friday masters Foe's recorders and repeatedly plays the tune of six notes Susan "associate with the island and Cruso's first sickness." ${ }^{[19]}$ Then, Friday plays it over and over on his little flute. Susan also plays "Friday's tune, first in unison with him, then in the intervals when he was not playing." ${ }^{,[19]}$ But she cannot keep playing the same tune on the flute, connecting it to her sense of superiority over Friday:

But alas, just as we cannot exchange forever the same utterances- "Good day, sir"- "Good day" and believe we are conversing, or perform forever the same motion and call it lovemaking, so it is with music: we cannot forever play the same tune and be content. Or so at least it is with civilized people. ${ }^{[19]}$

In this sense, the creation of a stereotype (civilized/uncivilized) can be interpreted as suggestive of an attempt on Susan's part to reassert her superiority over Friday. Friday is viewed through the lens of a negative stereotype. To put it simply, Friday is stereotyped as uncivilized. In the same vein, Durrant argues that Friday's lack of the name is a sign of the uncivilized. According to him, Friday is "the negative image of the Enlightenment subject: a sign of the uncivilized, the inhuman, the native, the infant. ${ }^{[32]}$

From the standpoint of Bhabha, these stereotypes create a doubleness-an ambivalence-that simultaneously causes anxiety in the colonizer. What is underlined here is that as Huddart mentions, "The colonizer [Susan] aggressively states his superiority to the colonized [Friday], but is always anxiously contemplating his own identity, which is never quite as stable as his aggression implies."[15] In spite of her being considered a civilized person, Susan cannot help expressing her doubt about her own identity. Susan falls into, to quote Macaskill and Colleran, "Beckettian doubt." ${ }^{[30]}$ Such feeling results in her sense of ambivalence and can be a menace to colonial discourse: "Nothing is left to me but doubt. I am doubt itself. Who is speaking me? Am I a phantom too? To what order do I belong?" ${ }^{[19]}$ She also defines herself as "a being without substance, a ghost beside the true body of Cruso." ${ }^{[19]}$ She beseeches Mr. Foe to return to her the substance she has lost: "For though my story gives the truth, it does not give the substance of the truth." ${ }^{[19]}$ Therefore, in order to find her voice, she needs the story of Friday's past life since what is essential to her identity is Friday's untold story 
about how he has lost his tongue. In Comparison with Bhabha, Edward said, to quote Nayar, argues that "the West built its identity in contrast with the East, by constantly drawing on this difference . . . of "us and them" ${ }^{[33]}$ and through inventing a series of binary oppositions and repeating stereotypes, but he does not mention anxiety on the part of the colonizer. To put it in another way, said defines colonial relations in terms of binary oppositions and ignores the psychic level of analysis and ambivalence which has been at the heart of Bhabha's theories of colonial discourses. For Bhabha ambivalence of colonial relations is something that disturbs the self-identity of the colonizer.

\section{CONCLuSion}

As observed, in this article the actions, behaviors and interactions of the characters were explored based on Bhabha's concepts of hybridity, unhomeliness and ambivalence. It can be said that Foe is an anti-colonial novel through which Coetzee attempts to depict the ambivalent condition of colonial discourse. As an aspect of hybridity, the feeling of unhomeliness is discernable in Susan, Friday and Cruso's cultural identity. As discussed, Susan, Friday and, to a lesser extent, Cruso experience unhomely moments and thus feel torn between the two cultures and identities. They live on borders and not feel at home in either cultures. As a result, this feeling of unhomeliness converts them, to quote Tyson, to "psychological refugees." ${ }^{[14]}$ They experience the feeling of never being able to find a pure sense of identity or culture. This situation mirrors Bhabha's claim that pure cultural identities do not exist; rather, they emerge from the hybridizing processes. During the course of the novel, Susan, Friday and Cruso experience ambivalence due largely to their feelings of unhomeliness.

Also, it can be concluded that the relationships between the characters operate in a much more complicated way rather than being observed in terms of fixed binary oppositions establishing a relation of authority. The relationship between Susan and Friday, through the process of stereotyping, reveals the inherently anxious foundations upon which Susan's authority as a colonizer rests, which is very much in line with Bhabha's concept of ambivalence. Thus, it can be understood that the location of culture, here, is between the cultures and the characters' identity is not fixed but hybridized. In other words, their cultures are unsteady and interwoven.

\section{REFERENCES}

[1] Ashcroft B., Griffiths G. and Tiffin H., The Post-colonial Studies Reader, Routledge, London, i (1995).

[2] Young R., Colonial Desire: Hybridity in Theory, Culture, and Race, Routledge, London, 154 (1995).

[3] McLeod J., Beginning Postcolonialism, Manchester University Press, Manchester, 51-53 (2000).

[4] Faith W. and McCallum P., Linked Histories: Postcolonial Studies in a Globalized World, University of Calgary, Calgary, 236 (2005).

[5] Chew S. and Richards D., A Concise Companion to Postcolonial Literature, Wiley-Blackwell, Malden, 20 (2010).

[6] Moore-Gilbert B. J., Postcolonial Theory: Contexts, Practices, Politics, Verso, London, 116 (2000).

[7] Head D., The Cambridge Introduction to J. M. Coetzee, Cambridge University Press, Cambridge, 1 (2009).

[8] Bonnici T., The contemporary post-colonial novel in English, Maringá. 26(1), 1-22 (2004).

[9] Attwell D., J. M. Coetzee: South Africa and the Politics of Writing, University of California, Berkeley, 25 (1993).

[10] Easton T. K. N., Text and hinterland: J. M. Coetzee and the South African novel, J South Afr Stud. 21(4), 585-599 (1995).

[11] Schwarz H. and Ray S., A Companion to Postcolonial Studies, Blackwell, Malden, 152 (2005).

[12] Habib M. A. R., A History of Literary Criticism and Theory: From Plato to the Present, Blackwell, Malden, 750 (2005).

[13] Bhabha H. K., The Location of Culture, Routledge, London, 25-107 (1994).

[14] Tyson L., Critical Theory Today: A User-friendly Guide, 2nd ed. Routledge, New York, 421 
(2006).

[15] Huddart D., Homi K. Bhabha, Routledge, London, 4-29 (2006).

[16] Tibile R., The location of culture: Homi K. Bhabha's new methodology of cultural analysis, TCIJE. 1(1), 12-16 (2010).

[17] Kraidy M. M., Hybridity in cultural globalization, Commun Theory. 12(3), 316-339 (2002).

[18] Tyson L., Using Critical Theory: How to Read and Write about Literature, Routledge, New York, 250 (2011).

[19] Coetzee, J. M., Foe, Penguin, New York, 8-133 (1986).

[20] Borbor T., Towards a new geographical consciousness: a study of place in the novels of V. S. Naipul and J. M. Coetzee, Ph. D. Thesis University of Sussex. UK. Pp. 262(2010).

[21] Krishna S., Globalization and Postcolonialism: Hegemony and Resistance in the Twenty-first Century, Rowman \& Littlefield, Plymouth, 95 (2009).

[22] Boehmer E., Iddiols K. and Eaglestone R., J.M. Coetzee in Context and Theory, Continuum, London, 163, (2009).

[23] Bongie, C., Islands and Exiles: The Creole Identities of Post/colonial Literature, Stanford University Press, Stanford, 39 (1998).

[24] Werbner, P., The limits of cultural hybridity: on ritual monsters, poetic licence and contested postcolonial purifications, J. R. Anthropol. Inst. 7(1), 133-152 (2001).

[25] Marais, M., Secretary of the Invisible: The Idea of Hospitality in the Fiction of J.M. Coetzee, Rodopi, Amsterdam, 74 (2009).

[26] Maher, S. N., Confronting authority: J.M. Coetzee's Foe and the remaking of Robinson Crusoe, Int. Fiction. Rev. 18(1), 34-40 (1991).

[27] Arkinstall, C., Literature and Quest, Rodopi, Amsterdam, 81 (1993).

[28] McEwan, C., Postcolonialism and Development, Routledge, London, 65 (2009).

[29] Britton, C. M., Edouard Glissant and Postcolonial Theory: Strategies of Language and Resistance, University Press of Virginia, Charlottesville, 119 (1999).

[30] Macaskill, B and Colleran J., Reading history, writing heresy: the resistance of representation and the representation of resistance in J. M. Coetzee's Foe, Contempt. Lit. 33(3), $432-457$ (1992).

[31] McRobbie, A., The Uses of Cultural Studies: A Textbook, Sage Publications, London, 110 (2005).

[32] Durrant, S., Postcolonial Narrative and the Work of Mourning: J.M. Coetzee, Wilson Harris, and Toni Morrison, State University of New York, Albany, 2 (2004).

[33] Nayar P. K., The Postcolonial Studies Dictionary, Wiley, Chichester, 119 (2015).

\section{AUTHORS' BIOGRAPHY}

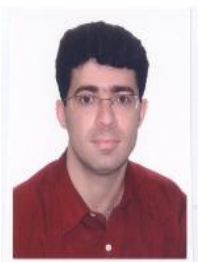

Alireza Farahbakhsh, from Iran. I am an associate professor at, and a member of the board of education, of University of Guilan, Iran. I received my $\mathrm{Ph} \mathrm{D}$ in English Literature from the University of Sussex, England, in 2004. I have published numerous translated articles in domestic journals as well as several books on English language and literature including Literary Schools and Movements for the Students of English Literature (2012), A Handbook of Critical Approaches (translation, 2008), Aristotle's Posterior Analytics (translation, 2008), British Drama for Students of English Literature (2008), A Short History of Literary Criticism: Plato to Derrida (2006), Passage Through Life (two volumes, translation, 2006), and Robinson Crusoe (translation, 1995). I have also supervised quite a few successful M. A. and $\mathrm{Ph} \mathrm{D}$ dissertations.

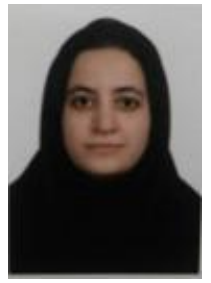

Rezvaneh Ranjbar, from Iran. I passed the Iranian National University Entrance Exam with ranking of 230 in 2009. I received my B. A. in English Literature from University of Guilan, Rasht, Iran in 2013. I was awarded University Honor of Study for the Master's Degree without taking Iranian National University Entrance Exam. I started studying M. A. in English Literature at University of Guilan in 2013 and currently I am doing my master's thesis on postcolonial studies. 